\title{
Development of a Method to Detect Cattle Material from Processed Meat Products Using a Polymerase Chain Reaction
}

\author{
Young Chul Kwon ${ }^{1}$, Do-Yun $\mathrm{Hah}^{2}$, Yunwi Heo ${ }^{3}$, Tae-Kyu Kim² ${ }^{2}$ Yoo-Jeong Choi ${ }^{2}$, Dae-Hoon Jo ${ }^{2}$, \\ Sang-Yun Nam ${ }^{2}$, Byeong-Guk Son ${ }^{2}$, Bo-Won Hwang ${ }^{2}$, Byoung-Seon Yang ${ }^{1}$, Euikyung Kim ${ }^{3}$ \\ ${ }^{1}$ Department of Medical Laboratory Science, Jinju Health College, Jinju, Korea \\ Gyeongnam Livestock Promotion Research Institute, Jinju, Korea \\ ${ }^{3}$ Department of Pharmacology and Toxicology, College of Veterinary Medicine, Gyeongsang National University, Jinju, Korea
}

\section{$\mathrm{PCR}$ 을 이용한 축산물 가공식품 내 소고기 성분 검출법 개발}

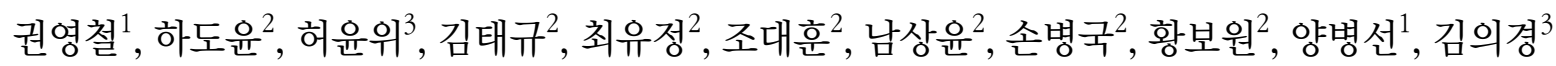 \\ ${ }^{1}$ 진주보건대학교 임상병리과, ${ }^{2}$ 경상남도 축산진흥연구소, ${ }^{3}$ 경상대학교 수의과대학 약리· 독성학교실
}

\begin{abstract}
Polymerase chain reaction (PCR) was used to detect cattle material from processed meat products. Seventy-eight different commercial processed meat products were purchased from several big food marts. Among them, 17 products contained cattle material (10 samples contained only cattle, 5 samples mixed with cattle and porcine, 2 samples mixed with cattle, porcine and chicken). The genomic DNA was extracted directly from the processed meat products, and strain-specific primer targeting the $16 \mathrm{~S}$ ribosomal RNA mitochondrial gene was used. All PCR products were cloned into the pGEM-T easy vector and sequenced. Consequently, the PCR products were amplified from 10 processed meat products, which contained only cattle material in our conditions. Furthermore, PCR reactions showed the same results at mixed samples. The DNA sequence obtained from pGEM-T easy/PCR products showed more than $95 \%$ identity with Bos taurus 16S rRNA gene using homology analysis. In conclusion, we suggest that the method using PCR, as performed in this study, could be useful in detecting cattle material in processed meat products. Moreover, our system could be applicable in inspection procedures to improve the verification of correct labeling for import and export processed meat products.
\end{abstract}

Key words: 16 s rRNA, Polymerase chain reaction, Processed meat products, Inspection programs

This is an Open Access article distributed under the terms of the Creative Commons Attribution Non-Commercial License (http://creativecommons.org/licenses/by-nc/4.0) which permits unrestricted non-commercial use, distribution, and reproduction in any medium, provided the original work is properly cited.

Copyright ( 2017 The Korean Society for Clinical Laboratory Science. All rights reserved.
Corresponding author: Byoung-Seon Yang Department of Medical Laboratory Science, Jinju Health College, 51 Uibyeong-ro, Jinju 52655, Korea

Tel: 82-55-740-1850

Fax: 82-55-743-3010

E-mail: ybseon@hanmail.net

Co-Corresponding author: Euikyung Kim Department of Pharmacology and Toxicology, College of Veterinary Medicine, Gyeongsang National University, 501 Jinju-daero, Jinju 52828, Korea

Tel: 82-55-772-2355

Fax: 82-55-772-2349

E-mail: ekim@gnu.ac.kr

Received: November 29, 2016

Revised $1^{\text {st: }: ~ J a n u a r y ~ 25, ~} 2017$

Revised 2 ${ }^{\text {nd. }}$ : March 28, 2017

Revised $3^{\text {rd: }}$ : March 31, 2017

Revised $4^{\text {th: }}$ : April 5, 2017

Revised $5^{\text {th }}$ : April 10, 2017

Accepted: April 10, 2017

\section{서 론}

우리나라에서의 축산물 소비는 고도 경제 성장 및 서구화된 식생활의 변화 등에 축산물 가공식품 위주로 폭발적으로 증가 해 왔다[1]. 그러나 축산물 가공식품은 식육 원재료를 직접 보고
구매하는 것과 다르게 가공과정에서 그 식육 원재료를 눈으로 확인 할 수 없기에 안정성 및 신뢰성 등의 문제점을 가지고 있다 [2]. 이로 인해 최근 값싼 식품원료를 사용하거나 식품의 원재료 명을 허위로 기재한 가짜 식품의 제조 및 유통으로 인하여 식품 의 안정성에 대한 불안감이 높아지고 있으며[3], 종교적 이유, 
알러지 물질과 같은 건강에 대한 우려 등과 같은 문제를 일으키 기도 한다[4]. 이에, 가공식품에 사용된 식육 원재료의 진위여부 를 확인 하여 품질이 우수하고 안정한 제품을 구별할 수 있는 과 학적인 시험법의 개발이 지속적으로 요구되어 왔다.

일반적으로 축산물 가공식품으로부터 축산물의 가공기준 및 성분규격으로 채택된 식육 원재료 감별법은 glycogen 검사법, 지방검사법 및 자비법이 있으나 감별기준이 모호하거나 검사자 의 주관적인 판단에 의해 결정되는 단점이 있다. 또 다른 방법으 로는 면역혈청침강반응, 미량겔 확산법 그리고 한천겔 확산법 이 있으나 다른 종의 단백질과 교차반응이 일어날 수 있는 단점 이 있다[5]. 이런 단점을 보완하기 위해서 보다 더 정확하고 감도 가 뛰어난 중합효소 연쇄 반응(polymerase chain reaction, $\mathrm{PCR})$ 법을 이용한 유전자 수준에서 검사하는 진단법이 개발되 어 오고 있다[6]. 특히, 미토콘드리아 유전자는 염기치환율이 유 전체 DNA 보다 빠르고, 상이한 DNA 분자 사이에 유전자 조환 이 발생하지 않는 모성유전을 하며[7] 종간 및 동종 내에 염기치 환에 의한 많은 돌연변이를 보유하고 있어[8,9] 품종의 기원, 품 종의 유전적 유연관계 및 유전적 차이를 구명하는데 매우 유용 한 도구로 이용되어 왔다[10-13]. 이런 이유로 축산물 가공식품 으로부터 특정 식육 원재료 물질의 혼합 유무를 조사하기 위하 여 미토콘드리아 $\mathrm{DNA}$ 를 표적으로 하는 PCR법이 개발되어 왔 다. 예를 들어, Soichi 등[14]은 돼지 미토콘드리아의 cytochrome $\mathrm{b}$ 유전자를 표적으로 하는 특이 primer를 이용한 real-time PCR 법을 개발하였으며, Hong 등[15]은 cytochrome b 유전 자를 표적으로 하여 토끼 및 고양이의 육류를 동시에 검출할 수 있는 duplex PCR법을 개발하였다. Koh 등[16]은 소고기, 돼지 고기 및 닭고기의 미토콘드리아 $12 \mathrm{~S}$ 와 $16 \mathrm{~S} \mathrm{rRNA}$ 유전자를 표 적으로 하는 특이 primer를 이용하여 multiplex PCR 방법을, Park 등[3]은 미토콘드리아 $12 \mathrm{~S}$ 및 $16 \mathrm{~S} \mathrm{rRNA}$ 유전자를 표적으 로 하는 특이 primer를 이용하여 축산물 가공식품의 사용원료 판별을 위한 PCR법을 개발 하였다. 하지만, 위의 방법들은 식육 원재료를 이용한 $\mathrm{PCR}$ 을 수행하였기 때문에, 햄, 소시지에서와 같이 식품 첨가물들이 많이 함유되어 있는 축산물 가공식품을 대상으로 특정한 식육 원재료 성분 검사를 위한 $\mathrm{PCR}$ 방법은 연 구가 부족한 실정이다.

이에 본 연구에서는, 기존의 축산물 식육 원재료에서 genomic DNA를 추출하여 PCR로 식육 원재료를 판별하는 방 법과는 다르게, 다양한 식품 첨가제가 함유되어 있는 축산물 가 공식품으로부터 직접 genomic DNA를 추출하고 소고기 성분 만을 검출할 수 있는 특이적인 primer를 제작한 후 축산물 가공 식품을 대상으로 소고기 성분을 검출 할 수 있는 PCR법을 개발
하고자 하였다.

\section{재료 및 방법}

\section{1. 재료}

축산물 가공식품으로부터 소고기 성분을 검출하기 위한 PCR 방법을 개발하기 위하여 경남 진주에 위치한 대형마트로 부터 소고기, 돼지고기 및 닭고기 성분이 함유되어 있는 축산물 가공식품 78 종류를 무작위로 구매하였다. 이들 중에, 소고기 성 분을 함유하는 축산물 가공식품은 떡갈비류 8개, 장조림류 1 개, 소세지류 2 개, 스테이크류 1 개, 그리고 탕류 5 개로 총 17 개였 다. 좀더 세분해 보면, 소고기만 함유되어 있는 가공식품은 10 개, 소고기와 돼지고기가 함유되어 있는 것은 5개, 그리고 소고 기, 돼지고기 및 닭고기가 모두 함유되어 있는 가공식품은 2개 였다(Table 1).

\section{Genomic DNA 추출 및 정량}

본 실험에 필요한 genomic DNA를 추출하기 위해서 Exgene $^{\mathrm{TM}}$ Cell SV kit (GeneAll Biotechnology, Seoul, Korea)를 이용하 여 제조사의 지침대로 실시하였다. 양성 대조군으로 소고기 식 육을, 음성 대조군으로 돼지고기, 닭고기 그리고 오리고기 식육 원재료를 이용하였다. 대조군 식육 원재료 및 축산물 가공식품 20 mg을 BioMasher II homogenizer (Nippi Skill, Tokyo, Japan)로 분쇄하여 제조사의 지침대로 순수한 genomic DNA 를 추출하였다. 추출된 genomic DNA는 NanoDrop ${ }^{\circledR} \mathrm{ND}-1000$ (Thermo Fisher Scientific, MA, USA)을 통하여 정량한 후 260/280 ratio가 1.8 2.0 사이의 순수한 DNA를 PCR 반응에 사용하였다.

\section{3. $P C R$ 반응}

축산물 가공식품으로부터 소고기 성분을 검출하기 위한 $\mathrm{PCR}$ 법을 개발하기 위해서, 소의 미토콘드리아 $16 \mathrm{~S} \mathrm{rRNA}$ 유전 자(Genebank accession no. V00654)를 이용하여 PCR 반응 산물의 크기가 $167 \mathrm{bp}$ 가 되게 primer (CF1 : 5'-CTCACAAACAGTTTACCAAGAAC-3', CR1 : 5'-CAAATAAACCCCACTGTAGC-3')를 직접 제작하였다. PCR 반응은, $5 \mathrm{ng} / \mu \mathrm{L}$ 농도 의 게놈 DNA를 사용하였으며, primer (10 pmole)는 forward 와 reverse를 각각 $2 \mu \mathrm{L}, \mathrm{dNTP}$ ( $2.5 \mathrm{mM}$ each) $4 \mu \mathrm{L}, 10 \mathrm{X}$ PCR buffer with $\mathrm{MgCl} 25 \mu \mathrm{L}$ 를 이용하여, KOD Neo pfu (Toyobo Biotechnology, Osaka, Japan) 중합효소를 첨가한 후, 멸균 증 류수로 최종 $50 \mu \mathrm{L}$ 가 되게끔 제조하여 $\mathrm{T} 100 \mathrm{PCR}$ 기기 
Table 1. The ingredient list of processed meat products

\begin{tabular}{|c|c|c|c|c|c|c|c|c|c|c|c|}
\hline No. & Por & Chic & Cat & No & Por & Chic & Cat & No & Por & Chic & Cat \\
\hline 1 & + & - & + & 27 & + & - & - & 53 & + & - & + \\
\hline 2 & + & - & - & 28 & + & - & - & 54 & + & - & - \\
\hline 3 & + & - & - & 29 & + & - & - & 55 & + & - & - \\
\hline 4 & + & - & - & 30 & + & + & - & 56 & - & + & - \\
\hline 5 & + & - & - & 31 & + & - & - & 57 & - & + & - \\
\hline 6 & + & - & - & 32 & - & + & - & 58 & - & + & - \\
\hline 7 & + & - & - & 33 & + & - & - & 59 & - & + & - \\
\hline 8 & + & - & + & 34 & + & - & - & 60 & - & + & - \\
\hline 9 & + & - & - & 35 & + & + & - & 61 & - & - & + \\
\hline 10 & + & - & - & 36 & + & - & - & 62 & + & - & - \\
\hline 11 & - & - & + & 37 & + & + & - & 63 & + & - & - \\
\hline 12 & - & - & + & 38 & + & - & + & 64 & - & - & + \\
\hline 13 & + & + & - & 39 & + & - & - & 65 & + & - & - \\
\hline 14 & - & + & - & 40 & + & - & - & 66 & + & - & - \\
\hline 15 & - & + & - & 41 & + & - & - & 67 & + & + & - \\
\hline 16 & - & + & - & 42 & + & - & - & 68 & + & - & - \\
\hline 17 & - & + & - & 43 & + & + & + & 69 & + & - & - \\
\hline 18 & - & + & - & 44 & + & + & + & 70 & + & - & - \\
\hline 19 & - & + & - & 45 & + & + & - & 71 & + & - & - \\
\hline 20 & - & + & - & 46 & + & - & - & 72 & + & + & - \\
\hline 21 & + & - & - & 47 & + & - & - & 73 & - & - & + \\
\hline 22 & + & + & - & 48 & + & - & - & 74 & - & - & + \\
\hline 23 & + & - & + & 49 & + & - & - & 75 & - & - & + \\
\hline 24 & + & - & - & 50 & + & - & - & 76 & - & - & + \\
\hline 25 & + & - & - & 51 & - & - & + & 77 & - & - & + \\
\hline 26 & + & + & - & 52 & + & - & - & 78 & - & + & - \\
\hline
\end{tabular}

Abbreviation: Por, Porcine; Chic, Chicken; Cat, Cattle; +, include target ingredient; -, exclude target ingredient.

(Bio-Rad Laboratories, CA, USA)를 이용하여 실시하였다. 본 실험에 사용한 $\mathrm{PCR}$ 반응조건으로는 $94^{\circ} \mathrm{C}$ 에서 10 분간 denaturation을 실시한 후 $94^{\circ} \mathrm{C}$ 에서 60 초, $62^{\circ} \mathrm{C}$ 에서 15 초, $72^{\circ} \mathrm{C}$ 에서 45 초를 $35 \mathrm{cycle}$ 로 한 후 $72^{\circ} \mathrm{C}$ 에서 5 분간 extension 후 $8^{\circ} \mathrm{C}$ 에서 종료하였다. 양성 대조군은 소고기 식육을, 음성 대조 군은 돼지고기, 닭고기 및 오리고기 식육 원재료로부터 추출한 genomic DNA을 이용하여 같은 방법으로 사용하였고, 최종 PCR 반응산물의 확인은 PCR 반응 산물에 6X DNA loading dye를 $10 \mu \mathrm{L}$ 첨가 하여 교반한 후 $10 \mu \mathrm{L}$ 를 취하여 $2 \%$ agarose gel로 $100 \mathrm{~V}, 30$ 분간 전기영동 하였다. PCR 산물의 크기를 확 인하기 위하여 $100 \mathrm{bp} \mathrm{DNA} \mathrm{ladder를} \mathrm{함께} \mathrm{전기영동} \mathrm{한} \mathrm{후,}$ $\mathrm{EtBr}(1 \mu \mathrm{g} / \mathrm{mL})$ 로 염색하여, Gel Doc ${ }^{\mathrm{TM}} \mathrm{EZ} \mathrm{Gel} \mathrm{Documentation}$ System (Bio-Rad Laboratories, CA, USA)을 이용하여 확인하 였다.

\section{4. $P C R$ 반응산물 염기서열 분석을 위한 cloning}

$\mathrm{PCR}$ 반응산물의 염기서열 분석을 위하여 $\mathrm{pGEM}{ }^{\circledR}$-T Easy Vector (Promega, WI, USA)를 사용하였다. 먼저, PCR 반응산 물을 Wizard ${ }^{\mathbb{R}}$ SV Gel and PCR clean-up System (Promega,
WI, USA)을 이용하여 agarose gel로부터 추출한 후, 10X A-attachment mix (Toyobo Biotechnology, Osaka, Japan) 를 이용하여 제조사의 지침대로 $\mathrm{dATP}$ 를 결합시켜 $\mathrm{pGEM}^{\mathbb{R}}$-T easy 플라즈미드와 T4 DNA ligase (Promega, WI, USA)를 이 용하여 cloning을 실시하였다. Cloning을 실시 후, E. coli $\mathrm{DH} 5 / \alpha$ (New England Biolabs, MA, USA)세포에 형질전환 시 킨 후, $\mathrm{LB}_{\mathrm{AMP}}$ 배지 ( $\mathrm{NaCl} 10 \mathrm{~g}$, Tryptone $10 \mathrm{~g}$, Yeast Extract 5 $\mathrm{g}$, Amphicillin $50 \mu \mathrm{g} / \mathrm{mL}$ )에 접종 후, $37^{\circ} \mathrm{C}$ 에서 1 일 동안 배양 을 시켰다. 배양 후, 자란 colony를 대상으로 plasmid DNA를 추출하여 제한효소 EcoRI (New England Biolabs, MA, USA) 을 이용하여 $37^{\circ} \mathrm{C}$ 에서 1 시간 처리하였다. 제한효소 처리 후, $2 \%$ agarose gel에 전기영동을 실시하여 클론을 확인하고, $\mathrm{DNA}$ 염기서열 분석을 의뢰하여 $\mathrm{DNA}$ 염기서열을 획득하였다. 획득된 DNA 염기서열의 상동성은 유전자은행의 blast 프로그 램(https://blast.ncbi.nlm.nih.gov/Blast.cgi?PROGRAM= blastn\&PAGE_TYPE=BlastSearch\&LINK_LOC=blasthome) 을 이용하여 분석하였다. 
결 과

축산물 가공식품으로부터 소고기 성분의 검출을 위한 $\mathrm{PCR}$ 법을 개발하기 위하여, 대조군의 축산물 식육 원재료(Figure 1A) 및 무작위로 구매한 78종의 축산물 가공식품을 대상으로 추출한 genomic DNA의 전기영동 결과 genomic DNA만 순수 하게 분리됨을 알 수 있었다(Figure 2). 추출된 genomic DNA 를 대상으로 본 연구에서 개발한 방법으로 PCR을 수행한 결과, 양성 대조군과 소고기 성분이 함유되어 있는 17 종의 가공식품 의 경우 $167 \mathrm{bp}$ 위치에 정확하게 PCR 반응산물이 나타났으나, 음성대조군(Figure 1B) 및 그 외의 축산물 가공식품에서는 PCR 반응산물이 전혀 나타나지 않았다(Figure 3). PCR 반응산 물의 DNA 염기서열 분석을 위해 cloning된 $\mathrm{pGEM}{ }^{\mathbb{R}}$-T Easy vector를 EcoRI을 반응 시킨 결과, $167 \mathrm{bp}$ 크기의 $\mathrm{PCR}$ 반응산 물이 cloning된 것을 확인 할 수 있었으며, 확인된 clone을 이용 한 염기서열 분석 결과 각각의 PCR 반응산물의 염기서열이 유
전자은행에 보고된 유전자와의 상동성이 $95 \%$ 이상 나타나는 것을 확인 할 수 있었다(Figure 4).

\section{고 찰}

우리나라의 경우 축산물 가공식품으로부터 축산물 식육 원 재료 성분검사에 대한 연구는 서구유럽의 선진국에 비하면 아 직은 미흡한 상태이다[2]. 따라서 소비자의 건강을 보호하고 [3], 종교적인 이유[2] 및 가짜식품의 근절을 위해, 축산물 식육 원재료 성분검사에 대한 연구의 필요성이 점점 부각되고 있는 추세이다. 최근, $\mathrm{Heo}$ 등[5]은, 식육 원재료 감별을 위한 PCR 및 ELISA 검사법에 대한 검증에서, 식육 원재료에 대한 ELISA 검사 에서는 거의 대부분의 축종에서 $90 \%$ 이상의 감별력을 나타났 지만, 분쇄가공품 및 식육추출가공품에서는 최대 $35.3 \%$, 최소 $12.5 \%$ 로 낮게 나타났으며, 2종 이상의 혼합육에서는 상대적으 로 낮은 감별력을 보였다고 보고하였다. 이런 이유로 여러 그룹
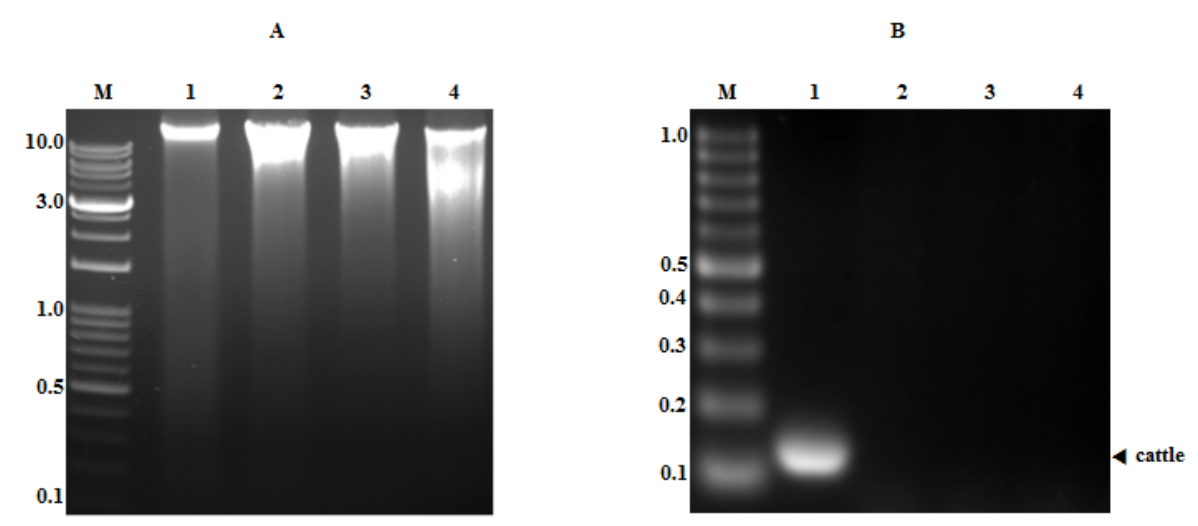

Figure 1. Total DNA and PCR products of control. (A) M: DNA size marker (0.1 10 Kb), total DNA electrophoresis on $1 \%$ agarose gel. (B) $M$ : DNA size marker $(0.1 \sim 3 \mathrm{~Kb}), \mathrm{PCR}$ products electrophoresis on $2 \%$ agarose gel. $1 \sim 4$ : cattle, pig, chicken and duck, respectively.

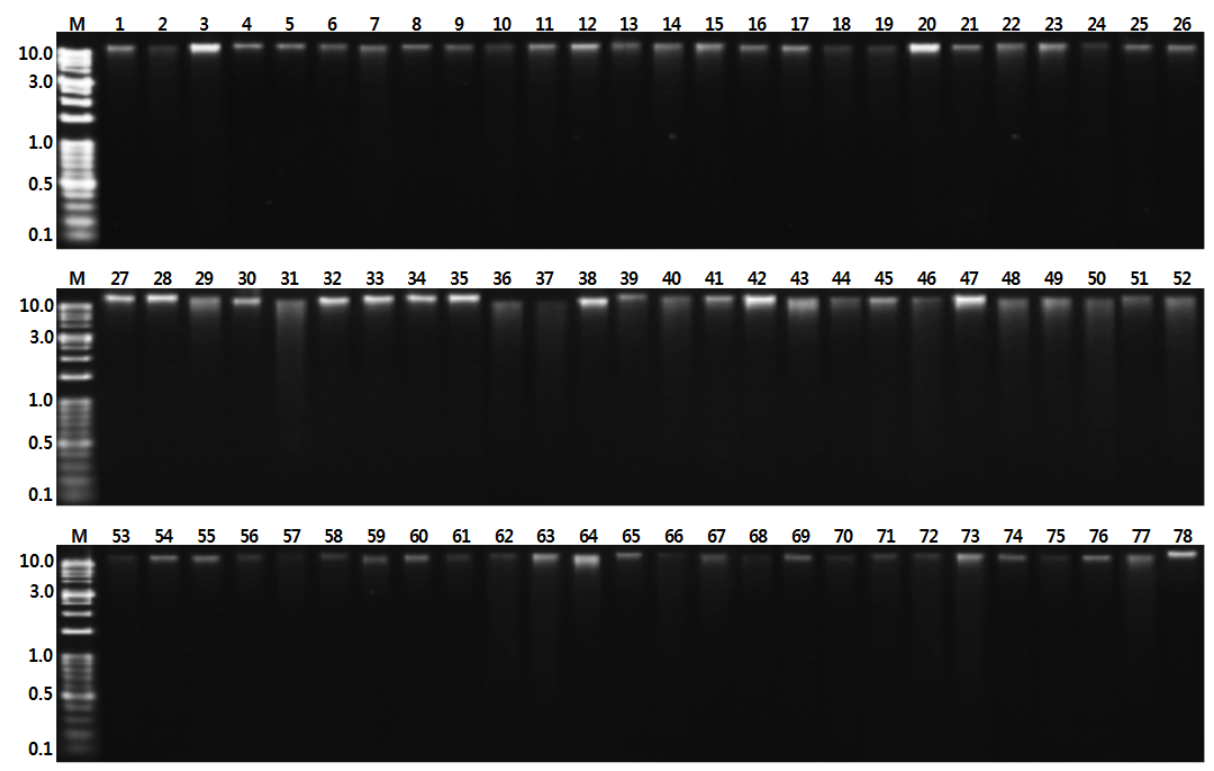

Figure 2. Total DNAs which were extracted from processed meat products. M: DNA size marker (0.1 10 Kb), 1 78: total DNAs from processed meat products, respectively. 


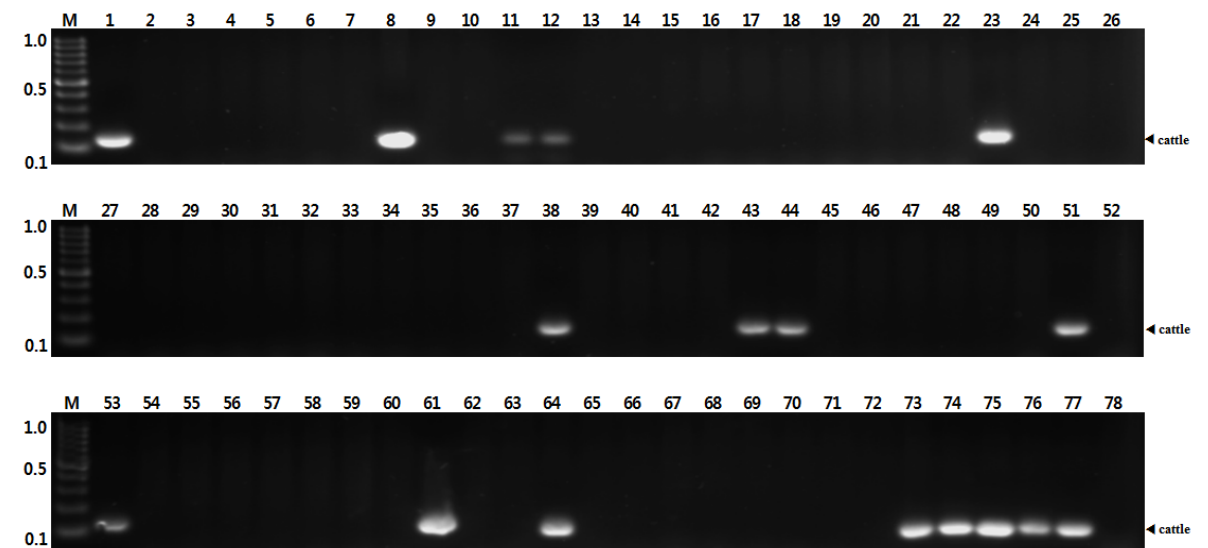

Figure 3. PCR products from total DNA of processed meat products. $M$ : DNA size marker (0.1 3 Kb), $1 \sim 78$ : PCR products from total DNA of processed meat products, respectively.
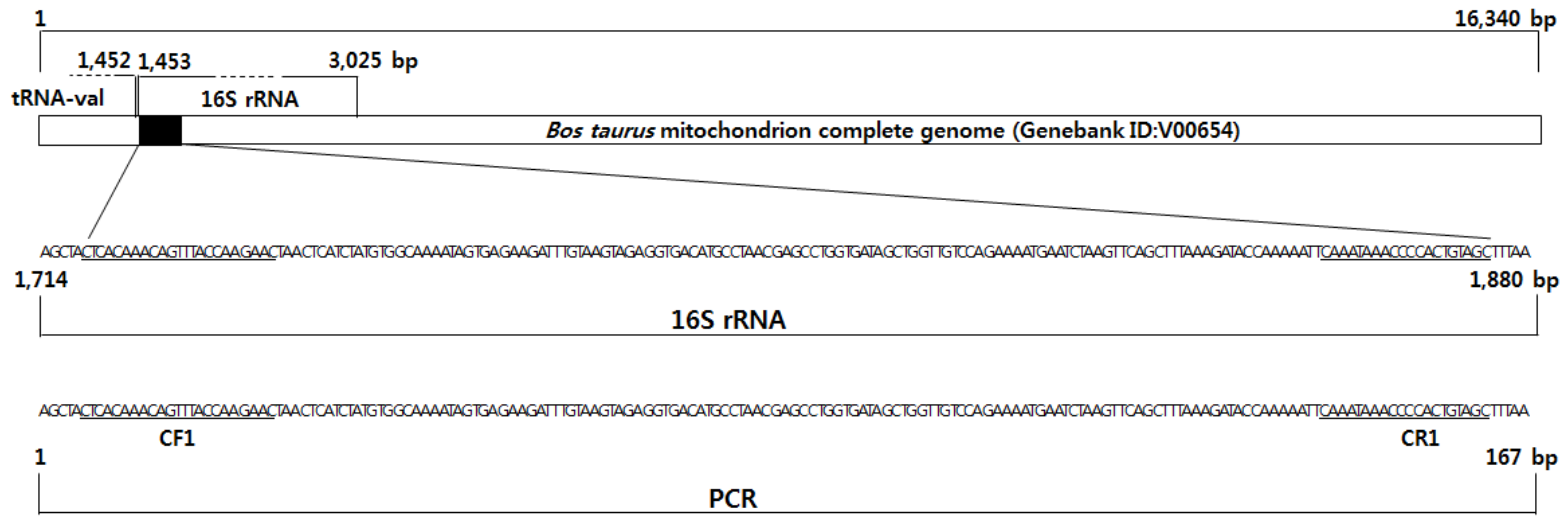

Figure 4. Homology analysis between $16 \mathrm{~S}$ rRNA gene of cattle and PCR products.

에서 식품 원재료의 미토콘드리아 DNA를 이용하여 신속하고 정확하게 식품 원재료를 검출 할 수 있는 분자생물학적 방법인 PCR법[3] 및 multiplex PCR법[16] 등이 계속적으로 개발되어 왔으나, 대부분의 경우 축산물 식육 원재료로부터 추출한 genomic DNA를 이용한 방법들로, 축산물 가공식품에서 직접 적용한 사례는 거의 존재하지 않는다. 본 실험에서도, 기존에 제 시된 여러 primer 조합으로 축산물 가공식품으로부터 추출한 genomic DNA를 대상으로 소고기 성분 검출을 적용해보았으 나, 비특이적 반응 산물이 생기거나 PCR 반응 억제 등의 다소 부 정확한 결과가 나타났다. 그 이유 중 하나가 PCR 반응에 사용된 genomic DNA의 농도에 의한 것이라 사료되었다.

$\mathrm{PCR}$ 수행에서 주형 $\mathrm{DNA}$ 의 농도는 매우 중요하며, 일반적으 로 주형 DNA의 농도가 너무 낮거나 너무 높아도 PCR 반응은 좋 지 않다[17]. Lahiff 등[18]이 발표한 보고에 의하면, 종 특이성 primer를 이용하여 양고기, 돼지고기 및 닭고기의 식육 원재료 감별을 위한 PCR 방법에서 조리된 식육에서 추출한 genomic $\mathrm{DNA}$ 의 농도가 식육 원재료에서 추출한 농도 보다 10 배 이상 낮 은 차이를 나타낸다고 보고하였다. 즉, 축산물 식육 원재료로부 터 추출한 genomic DNA의 량은 정량을 통해 모두 일정한 농도
로 사용할 수 있지만, 축산물 가공식품으로부터 추출한 genomic $\mathrm{DNA}$ 의 량은 첨가된 축산물 식육 원재료의 종류 및 함량에 따라 모두 다르게 존재한다. 본 실험에서도 축산물 식육 원재료로부 터 추출한 genomic DNA를 대상으로 한 PCR 반응은, 축산물 가공식품으로부터 추출한 genomic DNA 보다 훨씬 더 낮은 농 도 $(20 \mathrm{fg} / \mu \mathrm{L})$ 에서도 잘 수행되지만, 축산물 가공식품에서는 이 농도에서 PCR이 일부분만 수행되거나 전혀 되지 않았다. 이를 해결하기 위해서, 축산물 가공식품으로부터 추출한 genomic $\mathrm{DNA}$ 량을 점차적으로 증가시켜 반복적으로 수행해 본 결과, 축 산물 가공식품으로부터 소고기 성분의 첨가 유무를 정확하게 판별할 수 있는 PCR 조건을 확립 할 수 있었다. 이에 본 실험에 서 사용한 primer 서열, 주형 $\mathrm{DNA}$ 농도 및 $\mathrm{PCR}$ 조건을 적용한 다면 축산물 가공식품으로부터 소고기 성분의 함유 유무를 정 확하게 조사할 수 있을 것으로 기대된다.

$\mathrm{PCR}$ 반응산물의 정확성을 확인하기 위해서는 DNA 염기서 열을 분석하는 것이 가장 좋은 방법이다. 이를 위해, 축산물 가 공식품으로부터 PCR 반응 동안 변이가 생기지 않는 pfu 중합효 소를 사용하여 PCR 반응산물을 획득한 후, $\mathrm{dATP}$ 를 이용하여 A tailing 실시하고, $\mathrm{pGEM}^{\mathbb{R}}$-T Easy vector에 cloning을 실시하 
여 clone을 확보했다. 확보된 clone을 이용하여 획득한 PCR 반 응산물의 염기서열을 확인해 본 결과, 각각의 PCR 반응산물은 표적 유전자와의 상동성이 $95 \%$ 이상 높게 나타났다.

본 실험에서는 축산물 가공식품으로부터 소고기 성분을 정 확하게 검출할 수 있는 새로운 PCR 방법을 제시하고자 하였다. 본 실험에 사용된 방법으로 PCR 반응을 수행하면 축산물 가공 식품을 대상으로 소고기 성분의 함유 유무를 정확히 규명할 수 있을 것으로 기대되며, 나아가 식품 원료의 허위 기재로 인한 소 비자 건강보호 및 종교에 의한 금지 식품 조사 등에 대한 과학적 식품 감시가 가능할 것으로 사료된다.

\section{요 약}

중합효소연쇄반응법을 이용한 축산물 가공식품 내에 존재하 는 소고기 성분을 특이적으로 검출할 수 있는 방법을 개발하기 위하여 축산물 가공식품 78종류를 무작위로 선별하였다. 가공 식품으로부터 추출한 genomic DNA를 이용하여 소의 미토콘 드리아 $16 \mathrm{~S} \mathrm{rRNA}$ 염기서열을 이용하여 strain-specific primer 를 직접 제작하여 중합효소연쇄반응을 수행한 후, 증폭된 반응 산물의 염기서열을 분석 하였다. 축산물 가공식품 내 소고기 성 분 검출을 위한 중합효소연쇄반응 수행 결과, 소고기 성분이 함 유되어 있는 17 개의 축산물 가공식품이 정확히 증폭되었고, 증 폭산물의 DNA 염기서열 분석 결과 소의 미토콘드리아 $16 \mathrm{~S}$ rRNA 서열과 95\% 이상의 상동성을 보였다.

본 실험에서 제시된 방법으로 축산물 가공식품 내 소고기 성분 검출을 적용하였을 시, 소고기 성분이 함유된 축산물 가공식품을 정확하게 감별할 수 있었으며, 나아가 식품 원재료의 허위기재 등에 의한 불량식품 유통 근절 및 종교적 이유로 인한 금기 식품 감별 등과 같은 과학적 식품 감시에 기여할 수 있다고 사료된다.

\section{Acknowledgements: None}

Funding: This study was supported by a fund from Central Branch of Livestock Veterinary Promotion Research Institute of Republic of Korea.

Conflict of interest: None

\section{REFERENCES}

1. Han SH. Special Report-Meat Product. Food Engineering Progress. 1990;103-125.

2. Hsieh HM, Tsai CC, Tsai LC, Chiang HL, Huang NE, Shih RTP, et al. Species identification of meat products using cytochrome b gene. Forensic Science Journal. 2005;4(1):29-36.

3. Park YC, Ahn CY, Jin SO, Lim JY, Kim KH, Lee JH, et al. Identification of raw materials in processed meat products by PCR using species-specific primer. J Food Hyg Saf. 2012; 27(1):68-73.

4. Ballin NZ. Authentication of meat and meat products. Meat Science. 2010;86(3):577-587.

5. Heo EJ, Ko EK, Seo KH, Kim YJ, Park HJ, Wee SH, et al. Validation of PCR and ELISA test kits for identification of domestic animal species in raw meat and meat products in Korea. J Food Hyg Saf. 2014;29(2):158-163.

6. Yang BS. Detection of extended-spectrum $\beta$-lactamase producing Klebsiella pneumoniae by multiplex polymerase chain reaction. Korean J Clin Lab Sci. 2006;38(3):173-178.

7. Brown WM. Polymorphism in mitochondrial DNA of human as revealed by restriction endonuclease analysis. Proc Natl Acad Sci USA. 1980;77(6):3605-3609.

8. Brown WM, Prager EM, Wang A, Wilson AC. Mitochondrial DNA sequences of primates: tempo and mode of evolution. J Mol Biol. 1982;18(4):225-239.

9. Lansman RA, Avise JC, Aquadro CF, Shapira JF, Daniel SW. Extensive genetic variation in mitochondria DNA'S among geographic population of the deer mouse. Peromyscus maniculatus. Evolution. 1983;37(1):1-16.

10. Amano T, Miyakoshi Y, Tokada T, Kikkawa T, Suzuki M. Genetic variants of ribosomal DNA and mitochondrial DNA between swamp and river buffaloes. Anim Genet. 1994;25(1):29-36.

11. Kikkawa, Y, Amano T, Suzuki H. Analysis of genetic diversity of domestic cattle in East and Southeast Asia in terms of variations in restriction sites and sequences of mitochondrial DNA. Biochem Genet. 1995;33(1):51-60.

12. Mannen H, Kojima T, Oyama K, Mukai F, Ishida T, Tsuji S. Effect of mitochondrial DNA variation on carcass traits of Japanese black cattle. J Anim Sci. 1998;76(1):36-41.

13. Mannen H, Tsuji S, Loftus RT, Bradley DG. Mitochondrial DNA variation and evolution of Japanese black cattle (Bos taurus). Genetics. 1998;150(3):1169-1175.

14. Soichi T, Makiko H, Takeo Y, Masahiko S, Tatsuya F, Hiroshi A. A real-time quantitative PCR detection method for pork, chicken, beef, mutton, and horeseflesh in foods. Biosci Biotechnol Biochem. 2007;71(12):3131-3135.

15. Hong Y, Kim MJ, Yang SM, Yoo IS, Kim HY. Development of duplex PCR method for simultaneous detection of rabbit (Oryctolagus cuniculus) and cat (Felis catus) meats. J Appl Biol Chem. 2015;58(4):383-387.

16. Koh BRD, Kim JY, Na HM, Park SD, Kim YH. Development of species-specific multiplex PCR assays of mitochondrial $12 \mathrm{~S}$ rRNA and 16S rRNA for the identification of animal species. Korean J Vet Serv. 2011;34(4):417-428.

17. Bartlett JMS, Stirling D. PCR Protocols. 2nd ed. New York: Humana; 2003. p89-99.

18. Lahiff S, Glennon M, O’Brien L, Lyng J, Smith T, Maher M, et al. Species-specific PCR for the identification of ovine, porcine and chicken species in meat and bone meal (MBM). Mol Cell probes. 2001;15(1):27-35. 